\section{Economic Analysis of a Low-cost Apple Harvest-assist Unit}

\author{
Zhao Zhang and Paul H. Heinemann ${ }^{1}$
}

ADDITIONAL INDEX WORDS. tree fruit production, orchard mechanization, harvest efficiency, platform, harvest mechanization, labor reduction

Summary. A low-cost apple (Malus domestica) harvest-assist unit was recently developed to assist employees with fresh apple harvesting. This study reports on the economic analysis of this apple harvest-assist unit. Annual costs of the harvest-assist unit were calculated, including ownership and operational cost. Annual cost savings by increasing apple harvest efficiency, decreasing occupational injuries, improving work productivity in training, pruning, and thinning, and eliminating expenditures on purchasing ladders were calculated. When the annual costs are smaller than annual savings, the unit benefits apple orchard owners positively. Economic analysis results using orchard yields ranging from 25 to $45 \mathrm{Mg} \cdot \mathrm{ha}^{-1}$ demonstrated that when the apple orchard area was larger than $7.6 \mathrm{ha}$, the unit always benefited orchard owners positively; when the orchard area was smaller than 4.2 ha, the unit always benefited orchard owners negatively. For large orchards, more than one unit was required to satisfy the operational needs. Of the top four U.S. apple production states, Washington, New York, and Michigan, benefitted from purchasing four units, three units, and two units, respectively, per typical farm. However, an average-sized orchard in Pennsylvania, would not benefit, due to small orchard size and low yield. A net present value (NPV) analysis was determined using data from Washington State, which yielded a return on the 8-year investment in the machinery of $\$ 888.44$.

A pples, selected as one of the top 10 healthy foods (Nordqvist, 2016), rank second among American's favorite fresh fruits, with $9.5 \mathrm{lb}$ consumed per person in 2010 [U.S. Department of Agriculture (USDA), 2012]. Simultaneously, apple juice is the second highest volume juice consumed, just behind orange juice (Produce for Better Health Foundation, 2015). Currently, apples are commercially grown in 32 states in the United States, with a wholesale value of more than $\$ 2.7$ billion annually (U.S. Apple Association, 2016).

However, the U.S. apple industry is facing challenges (Schmoldt, 2007) including 1) a heavy dependence on a large seasonal workforce, 2) decreased availability of

Department of Agricultural and Biological Engineering, The Pennsylvania State University, University Park, PA 16802

The project was partially supported by funding from the Pennsylvania Department of Agriculture, The State Horticultural Association of Pennsylvania, the Penn State College of Agricultural Sciences, and the Penn State Department of Agricultural and Biological Engineering. We are indebted to Randall Bock, Tara Baugher, Jim Schupp, Roderick Thomas, John Schneider, Scott Gangel, Terry Salada, Alana Anderson, Edwin Winzeler, Tom Kon, Freeman Showers, and Eric Anderson for their valuable contributions.

${ }^{1}$ Corresponding author. E-mail: hzh@psu.edu.

doi: 10.21273/HORTTECH03548-16 employees, and 3) increased labor costs (Schupp et al., 2011). Ellis et al. (2010) reported harvesting as an area with the most significant need for improvement by advanced technologies. Improvements in harvest are needed because apples are picked manually by employees who carry them from trees to a bin using a bushel bucket, weighing as much as $40 \mathrm{lb}$ when fully filled. Employees wear the bucket during the entire harvest process on one side or in front of the body (Earle-Richardson et al., 2006a; Freivalds et al., 2006). In addition, apple harvest is potentially dangerous work. Apple harvest includes awkward activities, which can cause occupational injuries, such as neck, back, and shoulder strain and sprain (Earle-Richardson et al., 2006b). Zhang (2015) demonstrated that most of the awkward activities were related to ladder usage. The ladder usage decreased apple harvest efficiency, and previous research showed that employees spent $11.7 \%$ of the working time moving and climbing ladders. In addition, ladder fall accidents during apple harvest can cause serious injuries, such as fractures and open wounds, or even death (Fathallah, 2010; Fulmer et al., 2002; Smith et al., 2006; Stevens et al., 2006).

Considerable research was conducted to solve these issues by developing mechanical apple harvesters, eliminating ladder usage. Three prototype apple harvesters were developed but not commercialized by LeFlufy (1982a, 1982b, 1983), Millier et al. (1973), and Peterson and Wolford (2003). Research shifted to developing harvest-assist platforms to increase employees' apple harvest efficiency, decrease strength requirements for apple harvest, and eliminate ladders (Schupp et al., 2011; Zhang et al., 2016b). Currently, harvestassist machines are commercially available, but at high prices, ranging from $\$ 50,000$ to $\$ 130,000$ (Automated Ag, 2013; Jones, 2015; Lehnert, 2014; Milkovich, 2013). These machines may be affordable for large orchard owners, but may be too expensive for small orchard owners. Researchers at The Pennsylvania State University developed a low-cost apple harvestassist unit and field experiments, conducted in Fall 2014, showed bruising incidence below $5 \%$ and efficiency increases of 29\% (Zhang et al., 2014, 2016a). Bruising incidence sufficient to downgrade the apples harvested by this unit from extra fancy to fancy was within $5 \%$. In addition, the use of the machine demonstrated that ladders could be totally eliminated and awkward posture activities could be reduced during apple harvest. A survey administered during this project revealed that orchard owners were willing to pay up to $\$ 50,000$ for a mobile platform and an apple harvest-assist device, which could increase harvest efficiency by $25 \%$.

\begin{tabular}{llll}
\hline $\begin{array}{l}\text { Units } \\
\text { To convert U.S. to SI, } \\
\text { multiply by }\end{array}$ & U.S. unit & SI unit & $\begin{array}{l}\text { To convert SI to U.S., } \\
\text { multiply by }\end{array}$ \\
\hline 0.4047 & $\mathrm{acre}(\mathrm{s})$ & $\mathrm{ha}$ & 2.4711 \\
0.4536 & $\mathrm{lb}$ & $\mathrm{kg}$ & 2.2046 \\
0.9072 & ton $(\mathrm{s})$ & $\mathrm{Mg}$ & 1.1023 \\
2.2417 & ton(s)/acre & $\mathrm{Mg} \cdot \mathrm{ha}^{-1}$ & 0.4461
\end{tabular}


Reducing awkward posture activities could help to lower the seriousness of occupational injuries caused by apple harvest, which also helps improve employees' harvest efficiency.

One key goal of the low-cost apple harvest-assist project was to commercialize the machine. However, there are questions about the economic benefits of adopting the harvest-assist unit. The objective of this study was to assess the economics of the unit using l) a specific example based on fresh market apple production data and costs from Washington and Oregon, combined with efficiencies derived from use of the harvest-assist unit and 2 ) a range of calculated benefits based on costs and production data from the top four apple producing states in the United States.

\section{Materials and methods}

A low-cost apple harvest-assist unit was developed at the Department of Agricultural and Biological Engineering at The Pennsylvania State University, designed for twodimensional planar (trellised) orchards. It was field tested at the Biglerville Fruit Research and Extension Center (Adams County, PA), in Fall 2013 and 2014. The low-cost apple harvest-assist unit is shown in Fig. 1. The unit consists of five primary components: receiver, tube, manifold, distributor, and platform. Apples are placed into receivers after being picked. The apples then flow via gravity to the manifold through tubes. After exiting the manifold, the distributor assists with distributing apples evenly into the bin.

The harvest-assist device was attached to a mobile platform (EcoPick; ORSI Group, Bologna, Italy), powered by two $12-\mathrm{V}$ DC batteries and all wheel driven. The harvestassist unit only focuses on the upper canopy apples that require ladders for picking.

The low-cost apple harvestassist unit was assumed to operate $360 \mathrm{~h}\left(45 \mathrm{~d}\right.$ at $\left.8 \mathrm{~h} \cdot \mathrm{d}^{-1}\right)$ on harvest, and $800 \mathrm{~h}\left(100 \mathrm{~d}\right.$ at $\left.8 \mathrm{~h} \cdot \mathrm{d}^{-1}\right)$ on pruning, training, and thinning (PTT), for a total of $1160 \mathrm{~h}$ of use per year (Seavert et al., 2007). The useful life of the unit was assumed to be 8 years, which meant the unit could operate $9280 \mathrm{~h}$ before being replaced. Because the unit has not yet been commercialized, the price was conservatively estimated at $\$ 30,000$ based on the expenditures during development of this machine, including the cost of the ORSI platform. This unit was powered by three $12-\mathrm{V}$ DC batteries (two for the platform and one for electronic components, such as motors, sensors, and microchips), and the price included three extra $12-\mathrm{V}$ DC batteries. When the unit was operating, the three extra fully charged batteries were for backup to ensure no down time due to battery charging. Considering the

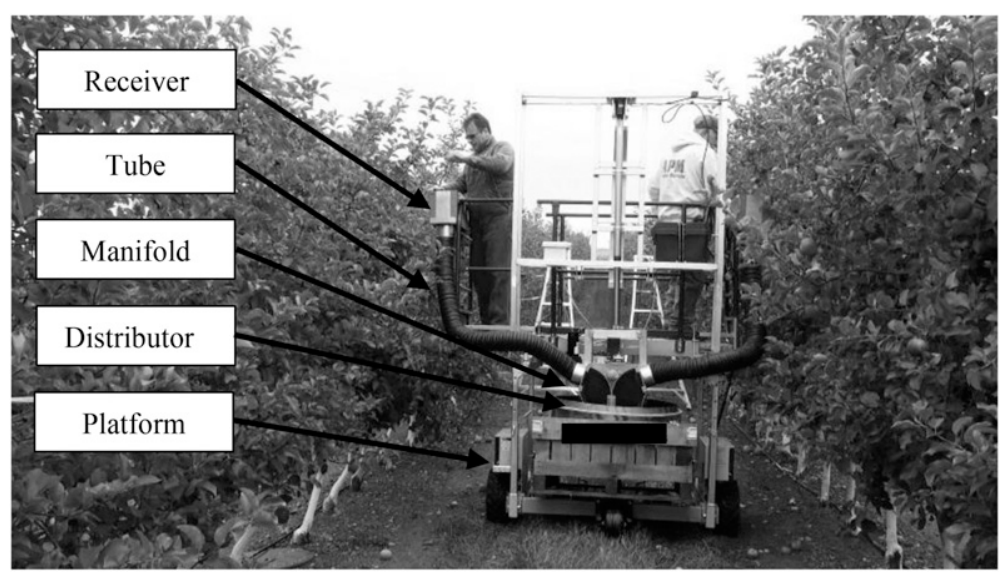

Fig. 1. Low-cost apple harvest-assist unit being field tested in Fall 2014. The unit is mounted on an "EcoPick" platform (ORSI Group, Bologna, Italy). The picker places the apples into the receiver, and the apples flow by gravity down the tube to the manifold. The manifold drops the apples vertically onto the distributor, which distributes the apples evenly into the bin.

limited annual usage, the batteries were assumed to function during the useful life of the unit.

AnNUAL COSTS OF THE LOW-COST APPLE HARVEST-ASSIST UNIT. Annual costs of the harvest-assist unit consist of two parts: annual ownership costs and operational costs [American Society of Agricultural and Biological Engineers (ASABE), 201la, 201lb]. Annual ownership costs (fixed costs) include depreciation, interest (opportunity cost), taxes, housing, and insurance. Operational costs include repairs, maintenance, and fuel (Edwards, 2015).

Depreciation, which reflects machine value reduction, is caused by wear, age of machine, and obsolescence. Age and accumulated hours of machine use are the two main factors affecting the depreciation. Salvage value is an estimated sale value of the machine at the end of its useful life, and it can be calculated through multiplying the machine price by salvage value factor. Considering the harvest-assist unit useful life of 8 years, the salvage value factor was conservatively assumed to be 0.1 for this study (Mizushima and $\mathrm{Lu}, 201 \mathrm{l}$; Zhang et al., 2016c).

Interest is an important factor in cost estimation. If the owneroperators borrowed money from a bank to purchase the machine, the bank would determine the interest rate. Interest rates for farm machinery, on an 8-year loan, ranged from $6.85 \%$ to $8.50 \%$ at the time of this study (AgChoice Farm Credit, 2016). However, if the apple orchard owners used their own capital, the interest rate would depend on the opportunity cost for the capital to be used elsewhere in the farm business. If the capital was partially borrowed from a bank, the rate should be a value between the two. In this research, the interest was assumed to be $8 \%$.

Taxes, insurance, and housing (TIH) are three other factors to be considered in the cost estimation, although usually they are much smaller than depreciation and interest. TIH can be estimated as percentage of purchasing price. ASABE standards (201lb) recommend a total of $2 \%$ of the purchase price of the machine as TIH, with taxes, housing, and insurance assumed as $1.00 \%, 0.75 \%$, and $0.25 \%$, respectively. 
Assuming a salvage value factor (0.1), machine life (8 years), annual interest rate $(8 \%)$, and $\mathrm{TIH}(2 \%)$, the total annual ownership costs were estimated as follows (ASABE, 201 lb):

$$
\begin{aligned}
C_{\mathrm{A}} & =P_{\mathrm{M}} \times C_{0} \\
C_{0} & =\frac{1-S_{\mathrm{V}}}{L}+\frac{1+S_{\mathrm{V}}}{2} \times i+K_{2}
\end{aligned}
$$

where $C_{\mathrm{A}}$ is annual ownership costs; $C_{0}$ is ownership cost coefficient; $P_{\mathrm{M}}$ is new machine purchase price $(\$ 30,000) ; S_{\mathrm{v}}$ is machine salvage value factor at the end of the machine useful life $(0.1) ; L$ is machine useful life ( 8 years); $i$ is annual interest rate (8\%); and $K_{2}$ is ownership cost factor, TIH (2\%). Repairs and maintenance are necessary to keep the harvest-assist unit operable due to wear and accidents. The annual repair and maintenance costs were estimated as:

$$
C_{\mathrm{rm}}=(\mathrm{RFI}) \times P_{\mathrm{M}} \times\left[\frac{h}{1000}\right]^{\mathrm{RF} 2}
$$

where $C_{\mathrm{rm}}$ is accumulated annual repair and maintenance costs; RFl is repair and maintenance factor one; RF2 is repair and maintenance factor two; $P_{M}$ is new machine purchase price; and $h$ is accumulated annual use of machine (hours). The relationship shown in Eq. [3] provides annual costs of all expenditures (part replacement, materials, shop expenses, and labor) to maintain a machine in a good working condition. Based on ASABE standards (201la), repair and maintenance factors 1 and 2 were obtained as 0.03 and 2 , respectively. The total power of the two batteries used to power the platform was $1600 \mathrm{~W}$. All other electric components were powered by the third battery. The power used by a linear actuator (part no. PPAl2-18B65-36NHSX; Thomson, Issy-les-Moulineaux, France) to lift the harvest device (distributor and manifold) when apples were filling the bin was $100 \mathrm{~W}$. A gearmotor (Dayton 12-V DC, model \#1Z833; W.W. Grainger, Pittsburgh, PA) used to spin the distributor required $130 \mathrm{~W}$. There were two other components that consumed electric energy: 1) a microchip that adjusted the distributor spinning speed and 2) an IR proximity sensor which detected the distributor spinning speed. However, both components consumed much less

Table 1. Harvest cost savings using apple harvest-assist device and platform based on different yield.

\begin{tabular}{lcccc}
\hline $\begin{array}{l}\text { Yield } \\
\left(\mathbf{M g} \cdot \mathbf{h a}^{-\mathbf{1}}\right)^{\mathbf{z}}\end{array}$ & $\begin{array}{c}\text { Time required } \\
\text { in conventional } \\
\text { harvest }(\mathbf{h})\end{array}$ & $\begin{array}{c}\text { Time saved } \\
\text { by adopting } \\
\text { harvest-assist } \\
\text { unit }(\mathbf{h})^{\mathbf{y}}\end{array}$ & $\begin{array}{c}\text { Cost } \\
\text { savings }(\$)^{\mathbf{x}}\end{array}$ & $\begin{array}{c}\text { Machine-covered } \\
\text { area (ha) }\end{array}$ \\
\hline 25 & 67.1 & 15.1 & 301.7 & 12.0 \\
30 & 80.5 & 18.1 & 361.9 & 10.0 \\
35 & 93.9 & 21.1 & 422.2 & 8.6 \\
40 & 107.3 & 24.1 & 482.4 & 7.5 \\
45 & 120.7 & 27.1 & 524.7 & 6.7 \\
\hline
\end{tabular}

${ }^{\mathrm{z}} \mathrm{l} \mathrm{Mg} \cdot \mathrm{ha}^{-1}=0.4461$ ton/acre.

${ }^{y}$ Calculated with harvest efficiency improvement of $29 \%$.

${ }^{\mathrm{x}}$ Calculated with harvest labor cost of $\$ 20 / \mathrm{h}$.

${ }^{\mathrm{w}}$ Calculated with machine capacity of $150 \mathrm{Mg}$ (165.3 tons) per harvest season; 1 ha $=2.4711$ acres.

\begin{tabular}{|c|c|c|c|c|}
\hline $\begin{array}{l}\text { Yield } \\
\left(\mathrm{Mg}^{-h^{-1}}\right)^{\mathrm{z}}\end{array}$ & $\begin{array}{c}\text { Time required } \\
\text { for conventional } \\
\text { harvest }(\mathrm{h})\end{array}$ & $\begin{array}{c}\text { Time saved } \\
\text { by adopting } \\
\text { harvest-assist } \\
\text { unit }(h)^{y} \\
\end{array}$ & $\begin{array}{c}\text { Cost savings } \\
(\$ / \mathrm{ha})^{\mathrm{x}}\end{array}$ & $\begin{array}{l}\text { Machine-covered } \\
\text { area (ha) }\end{array}$ \\
\hline 25 & 67.1 & 1.3 & 26.3 & 12.0 \\
\hline 30 & 80.5 & 1.6 & 31.6 & 10.0 \\
\hline 35 & 93.9 & 1.8 & 36.8 & 8.6 \\
\hline 40 & 107.3 & 2.1 & 42.1 & 7.5 \\
\hline 45 & 120.7 & 2.4 & 47.3 & 6.7 \\
\hline
\end{tabular}

Table 2. Cost savings resulting from reduction in occupational injuries based on various apple yields.

${ }^{\mathrm{z}} \mathrm{l} \mathrm{Mg} \cdot \mathrm{ha}^{-1}=0.4461$ ton/acre.

${ }^{y}$ Calculated with harvest efficiency improvement of $2 \%$ through decreasing occupational injuries

${ }^{\mathrm{x}}$ Calculated with harvest labor cost of $\$ 20 / \mathrm{h} ; \$ 1 / \mathrm{ha}=\$ 0.4047 /$ acre.

${ }^{\mathrm{w}}$ Calculated with the machine capacity of $150 \mathrm{Mg}$ (165.3 tons) per harvest season; 1 ha $=2.4711$ acres.

Table 3. Pruning, training, and thinning cost savings using platform based on various apple yields.

\begin{tabular}{lcccc}
\hline $\begin{array}{l}\text { Yield } \\
\left(\mathbf{M g}^{\prime} \mathbf{h a}^{-\mathbf{l}}\right)^{\mathbf{z}}\end{array}$ & $\begin{array}{c}\text { Time required } \\
\text { for CPTT }(\mathbf{h})\end{array}$ & $\begin{array}{c}\text { Time saved } \\
\text { by using } \\
\text { platform }(\mathbf{h})^{\mathbf{y}}\end{array}$ & $\begin{array}{c}\text { Cost savings } \\
(\mathbf{\$} / \mathbf{h a})^{\mathbf{x}}\end{array}$ & $\begin{array}{c}\text { Machine-covered } \\
\text { area (ha) })^{\mathbf{w}}\end{array}$ \\
\hline 25 & 144.8 & 48.3 & 555.3 & 12.0 \\
30 & 173.8 & 57.9 & 666.3 & 10.0 \\
35 & 202.8 & 67.6 & 777.4 & 8.6 \\
40 & 231.8 & 77.3 & 888.4 & 7.5 \\
45 & 260.7 & 86.9 & 999.5 & 6.7 \\
\hline
\end{tabular}

CPTT $=$ conventional pruning $/$ training/thinning approach .

${ }^{\mathrm{z}} 1 \mathrm{Mg} \cdot \mathrm{ha}^{-1}=0.4461$ ton/acre.

${ }^{y}$ Calculated with working efficiency improvement of $50 \%$

${ }^{\mathrm{x}}$ Calculated with the labor cost of $\$ 11.50 / \mathrm{h} ; \$ 1 / \mathrm{ha}=\$ 0.4047 /$ acre

${ }^{\text {w}}$ Calculated with the machine capacity of $150 \mathrm{Mg}$ (165.3 tons) per harvest season; $1 \mathrm{ha}=2.4711$ acres.

energy compared with the motors. The power requirement for the two components was assumed to be $1 \mathrm{~W}$. All energy was provided by $12-\mathrm{V}$ DC batteries, and while charging these batteries, a coefficient of 1.05 was assumed because some of the electric energy is wasted (such as heat) during charging. The electricity cost was assumed to be $\$ 0.18 / \mathrm{kWh}$ (U.S. Energy Information Administration, 2016).

MaChINe CAPACITy AND MACHINE COVERAGE AREA. These two terms are defined as the total weight of apples harvested in a growing season and the total number of hectares harvested in a growing season, respectively, by the harvest-assist device. Machine capacity (MC) is based on apple weight and is calculated using Eq. [4]:

$$
\mathrm{MC}=\mathrm{Htp} \times \mathrm{THT} \times \frac{\mathrm{Wa}}{1000}
$$

where Htp is harvester throughput (0.78 apples/s) (Zhang et al., 2014); 
THT is total harvest time $(1.296 \times$ $10^{6} \mathrm{~s}$, assuming $8 \mathrm{~h} \cdot \mathrm{d}^{-1}$ and $45 \mathrm{~d}$ harvest); and Wa is weight of apple (0.15 $\mathrm{kg}$ /apple).

Machine-covered area (MCA) is determined using Eq. [5]:

$$
\mathrm{MCA}=\frac{\mathrm{MC}}{(0.5 \times \mathrm{OY})}
$$

where OY is orchard yield (megagrams per hectare), and 0.5 is a factor accounting for the fact that about one half of the apples are in the upper canopy and are harvested by pickers standing on the platform.

Table 4. Ladder savings based on apple yield. Ladders are needed for multiple operations, including harvest, training, pruning, and thinning, which can all be replaced by the platform.

\begin{tabular}{|c|c|}
\hline $\begin{array}{l}\text { Yield } \\
\left({\left.\mathrm{Mg} \cdot \mathrm{ha}^{-1}\right)^{\mathrm{z}}}\right.\end{array}$ & $\begin{array}{c}\text { Ladder cost } \\
\text { saving }(\$ / \mathrm{ha})^{\mathrm{z}} \\
\end{array}$ \\
\hline 25 & 22.0 \\
\hline 30 & 26.4 \\
\hline 35 & 30.8 \\
\hline 40 & 35.2 \\
\hline 45 & 39.6 \\
\hline
\end{tabular}

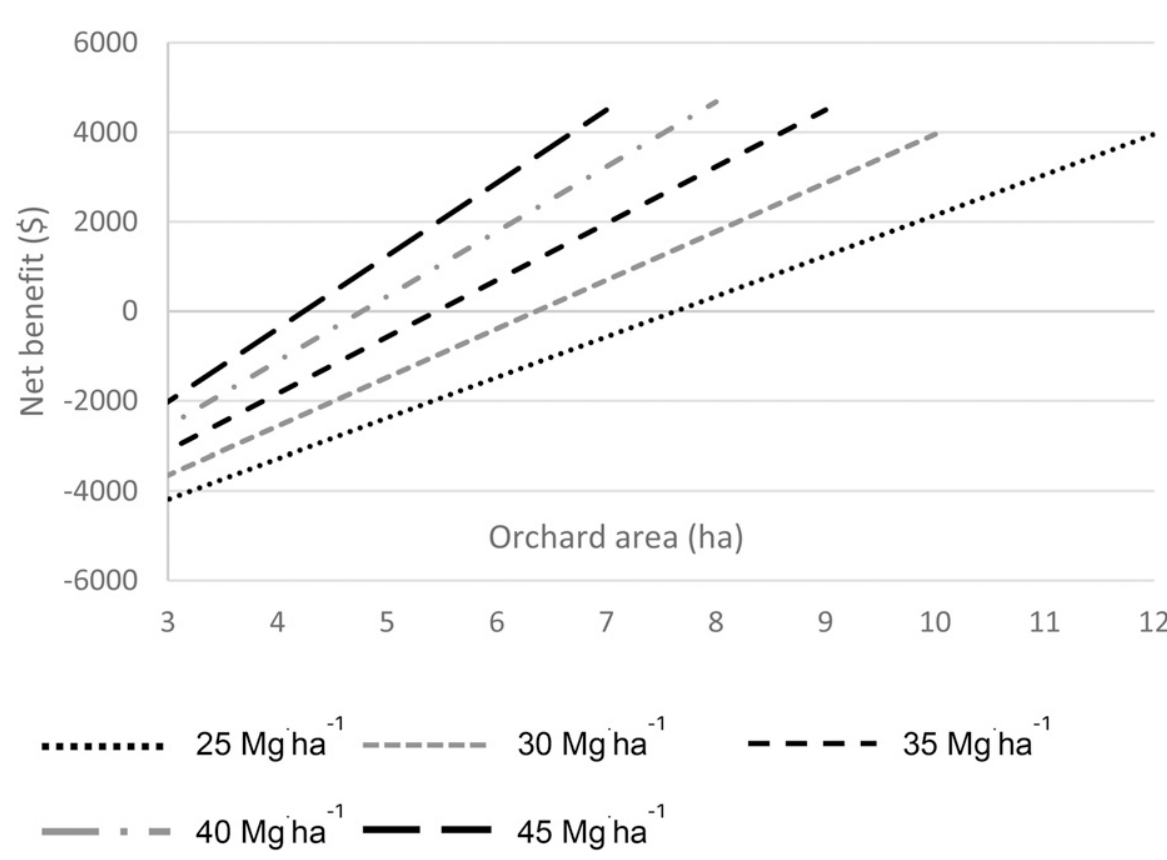

Fig. 2. Benefits for one harvest-assist unit (device and platform) under different apple orchard areas and yields. Higher yields result in a lower orchard area threshold, as shown by the benefit line crossing into positive space at a lower size, e.g., the $45{\mathrm{Mg} \cdot \mathrm{ha}^{-1}}$ threshold is at about $4.2 \mathrm{ha}$, the $25 \mathrm{Mg} \cdot \mathrm{ha}^{-1}$ is at $7.6 \mathrm{ha}$; $1 \mathrm{ha}=$ 2.4711 acres, $1 \mathrm{Mg} \cdot \mathrm{ha}^{-1}=0.4461$ ton/acre . apple harvest, the harvest efficiency was increased by $29 \%$ compared with ladders; and 3 ) when pickers stood on the platform to harvest apples, the harvest rate was 0.39 apples $/ \mathrm{s}$ for each person (0.78 apples/s for the unit with two pickers working on the platform simultaneously).

Cost SAVINGS BY DECREASING ocCUPATIONAL INJURY. Brower et al. (2009) reported that the occupational injury had a 5\% incidence among farmworkers. Earle-Richardson et al. $(2004,2006 a, 2006 b)$ and Fulmer et al. (2002) demonstrated that the leading occupational injury type during apple harvest was the back, neck, and shoulder sprain/ strain, which accounted for $37 \%$ of all occupational injuries, and the second most common injury was ladder fall, which constituted $12 \%$ of all occupational injuries. Zhang (2015) demonstrated that by adopting the harvest-assist unit, $34 \%$ of the back, neck, and shoulder sprain/ strain was eliminated. Taylor et al. (2008) reported that back, neck, and shoulder sprain/strain injuries reduced work productivity by $15 \%$. The overall harvest productivity for these types of injury can be calculated using Eq. [6].

$$
\mathrm{EI}=\left(\frac{1}{1-\mathrm{RE}}-1\right) \times \mathrm{ER} \times \mathrm{OII} \times \mathrm{SI}
$$

where EI is efficiency increase; RE is reduced efficiency (15\%); ER is percent occupational injuries eliminated by use of platform [34\% (Zhang, 2015)]; OII is occupational injury incidence (5\%); and SI is sprain and strain incidence of back, neck, and shoulder $(37 \%)$.

O'Sullivan et al. (2004) reported that tissue injuries from ladder falls would result in 1-month unemployment, and fractures would result in at least 4-month unemployment. It was reasonable to assume that one person lost all productivity once the person fell off a ladder during apple harvest if a serious injury occurred. The efficiency increase for eliminating these types of injury can be calculated using Eq. [6].

Cost SAVINGS BY IMPROVING WORKING EFFICIENCY IN APPLE TREE PTT. The platform on which this harvest-assist device was mounted provides additional capacity for orchard 
production operations. Experiments using similar platforms on PTT activities were conducted by Baugher et al. (2009) and Sazo et al. (2010). These studies demonstrated that mobile orchard platforms increased worker productivity in PTT by $\approx 50 \%$ for each. In this research, the platform was assumed to be used for PTT for $800 \mathrm{~h}$ each year.

Cost SAVINGS BY ELIMINATING EXPENDITURES ON LADDER PURCHASE. Ladders have multiple uses, and in conventional production approaches they are required for harvesting, pruning, thinning, and training. Gallardo and Galinato (2012)

Table 5. Orchard area threshold based on apple yield. The orchard area threshold is defined as the orchard area below which purchasing and operating the harvest-assist unit would result in a net cost rather than net savings.

\begin{tabular}{lc}
\hline $\begin{array}{l}\text { Yield } \\
\left(\mathbf{M g}^{\prime} \mathbf{h a}^{-1}\right)^{\mathbf{z}}\end{array}$ & $\begin{array}{c}\text { Orchard area } \\
\text { threshold }(\text { ha })^{\mathbf{z}}\end{array}$ \\
\hline 45 & 4.2 \\
40 & 4.8 \\
35 & 5.5 \\
30 & 6.4 \\
25 & 7.6 \\
\hline
\end{tabular}

${ }^{\mathrm{z}} 1 \mathrm{Mg} \cdot \mathrm{ha}^{-1}=0.4461$ ton/acre, $1 \mathrm{ha}=2.4711$ acres.

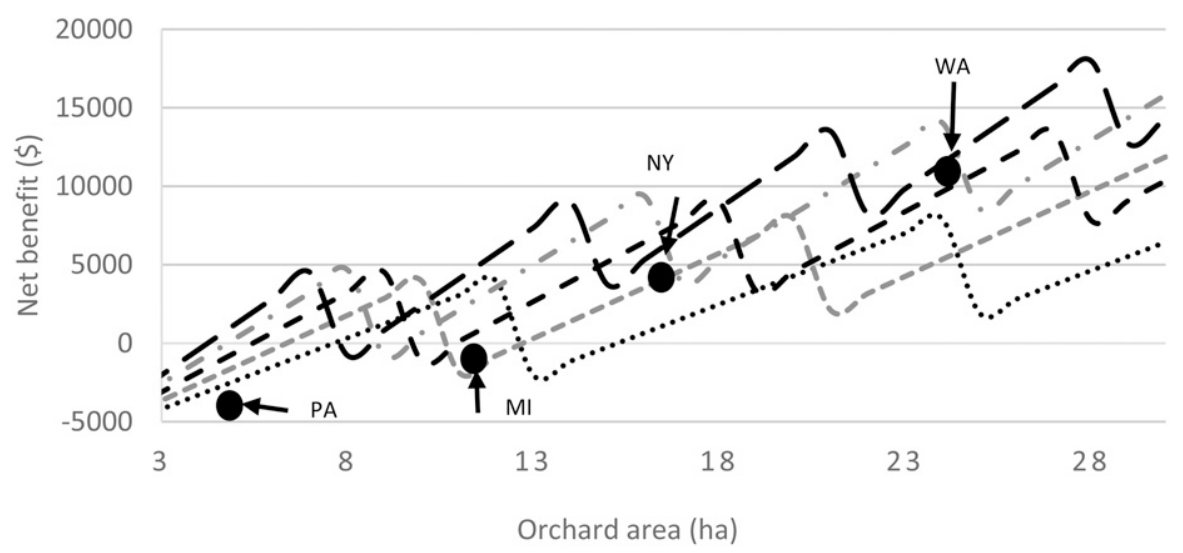

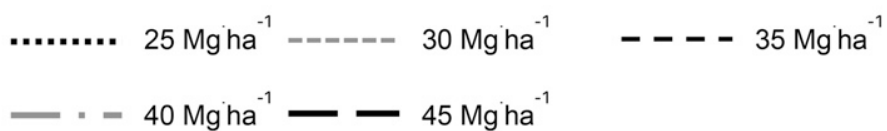

Fig. 3. Benefits for multiple harvest-assist units and benefits at different apple orchard areas and yields. The dip in the curves from left to right show the addition of another harvest-assist unit, starting from left with one unit and ending on the right with five units. Average-sized Pennsylvania (PA) orchards would potentially lose money using the harvest-assist unit, whereas average-sized Michigan (MI), New York (NY), and Washington (WA) orchards would have a financial benefit using the harvest-assist unit; 1 ha $=2.4711$ acres, $1 \mathrm{Mg} \cdot \mathrm{ha}^{-1}=0.4461 \mathrm{ton} /$ acre .
(25.55 to $\left.45.95 \mathrm{Mg} \cdot \mathrm{ha}^{-1}\right)$ (Mizushima and $\mathrm{Lu}, 2011$; USDA, 2016).

NPV ANALYsIs. Determining the NPV of the machine can assist owner-operators with the purchasing decision (Julian and Seavert, 2011 ; Kien Hwa, 2008). A positive NPV suggests that the overall investment will bring positive benefits, and it is worthwhile for owner-operators to purchase the machine. The NPV is calculated using Eq. [7] (Julian and Seavert, 2011).

$$
\begin{aligned}
\mathrm{NPV} & =-P_{M} \\
+ & \sum_{n=1}^{7}\left\{\frac{\left(1-S_{v}\right)}{L} \times \frac{P_{M}}{(1+i)^{n}}\right. \\
+ & \left.\frac{\left[B_{A M B}-\left(\frac{i}{2}+S_{v} \times \frac{i}{2}+K_{2}\right)\right.}{(1+i)^{n}}\right\} \\
+ & \frac{\left(1-S_{v}\right)}{L} \times \frac{P_{M}}{(1+i)^{8}} \\
+ & \frac{\left[B_{A M B}+S_{v}-\left(\frac{i}{2}+S_{v} \times \frac{i}{2}+K_{2}\right)\right.}{(1+i)^{8}}
\end{aligned}
$$

where $B_{\mathrm{AMB}}$ is the annual machine benefits.

\section{Results and discussion}

COST SAVINGS BY INCREASING APPLE HARVEST EFFICIENCY. Gallardo and Galinato (2012) and Seavert et al. (2007) estimated picking labor costs of $\$ 1002 /$ acre $(\$ 2476.0 / \mathrm{ha})$ for an orchard yielding 20.5 tons/acre. Using this yield in Eq. [5], the MCA was calculated as 7 ha. Using a harvest efficiency increase of $29 \%$ by adopting the harvest-assist device and picking labor costs of $\$ 2475 /$ ha, cost savings based on various yields are shown in Table 1 .

Cost SAVINGS BY DECREASING OCCUPATIONAL INJURY. The partial elimination of the back, neck, and shoulder sprain/strain injuries by using the harvest-assist unit resulted in an overall harvest productivity increase of $0.11 \%$, as calculated by Eq. [6]. Eliminating ladder fall accidents increased the harvest efficiency by $0.6 \%$ using Eq. [6]. Partially solving the sprain/strain issue and fully solving the ladder fall problem resulted in an overall apple harvest efficiency increase of $0.71 \%$. In addition, considering the limited data on the more serious results of death caused by ladder falls, the final harvest efficiency 
improvement through eliminating ladder usage was determined as $2 \%$ (Zhang et al., 2016c). The cost savings based on these results by yield are shown in Table 2.

Cost SAVINGS BY IMPROVING WORKING EFFICIENCY IN APPLE TREE PTT. The platform increases worker efficiency for the PTT tasks. Seavert et al. (2007) reported PTT costs were $\$ 1376 /$ acre $(\$ 3400.2 / \mathrm{ha})$, assuming an orchard yield of 20.5 tons/acre. Using the $50 \%$ efficiency improvement figure, considerable potential savings were determined as shown in Table 3.

Cost SAVINGS BY ELIMINATING EXPENDITURES ON LADDER PURCHASE. Using the mobile orchard platform essentially eliminates the need for ladders. The savings for different yields were calculated and are shown in Table 4.

NET BENEFIT BASED ON ORCHARD AREA AND YIELDS. The benefits of one unit with different area and yields were calculated and are shown in Fig. 2, based on the MC of $150 \mathrm{Mg}$ (165.3 tons) per harvest season. Since few apple orchards in the United States have an area smaller than 3 ha or larger than 30 ha (Zhang et al., 2016c), the apple orchard areas presented range from 3 to 30 ha in Fig. 2 .

Orchard area thresholds for various yields are shown in Table 5 . The higher the orchard yield, the lower the threshold. Considering a typical orchard in one of the four top apple producing states, if the orchard has an area larger than 7.6 ha, a single harvest-assist unit results in positive benefits. However, if the orchard area is smaller than 4.2 ha, the result is negative. Thus, the potential market for this harvest-assist unit is an orchard larger than 4.2 ha. For one unit, within the $\mathrm{MC}$, the larger the farm size (larger than $4.2 \mathrm{ha}$ ), the more positive benefit the machine could bring, and the maximum benefits are about $\$ 5000$ for a single unit.

UNIT QUANTITY NEEDED AND BENEFITS FOR DIFFERENT ORCHARD AREAS AND YIELDS. When orchard yields ranged from 25 to $45 \mathrm{Mg} \cdot \mathrm{ha}^{-1}$ (11.2 to 20.1 tons/acre), the MCA ranged from 12 to 7 ha $(29.7$ to 17.3 acres). For larger apple orchards, more than one unit would be needed. The number of units needed was determined by dividing the MC by the orchard total yield. For example,

Table 6. Harvest-assist device and platform adoption benefit sources and percent of benefit per hectare [apple yields at $40 \mathrm{Mg} \cdot \mathrm{ha}^{-1}$ (17.8 tons/acre)].

\begin{tabular}{lcc}
\hline Benefit sources & Benefits $(\$ / \mathbf{h a})^{\mathrm{z}}$ & Percent of total \\
\hline Harvest efficiency increase & 482.4 & 33.3 \\
Occupation injury decrease & 42.1 & 2.9 \\
PTT efficiency improvement & 888.4 & 61.3 \\
Cost elimination in purchasing & 35.2 & 2.4 \\
$\quad$ ladders & & \\
Total & 1448.1 & 100 \\
\hline
\end{tabular}

$\mathrm{PPT}=$ pruning, training, and thinning.

${ }^{\mathrm{z}} \$ 1 / \mathrm{ha}=\$ 0.4047 /$ acre.

Table 7. Net present value analysis result. The initial purchase price $\left(P_{M}\right)$ of $\$ 30,000$ is based on cost of the platform plus the harvest-assist component. The positive cash flow is based on savings compared with conventional harvest using ladders and buckets for all picking activities. The analysis was based on the following inputs: salvage value factor $(S v)$ is 0.1 ; machine useful life $(L)$ is 8 years; annual machine benefits $\left(B_{\mathrm{AMB}}\right)$ is $\$ 5250$ /year; annual interest rate $(i)$ is $8 \%$; ownership cost factor $\left(K_{2}\right)$ is $2 \%$; accumulated yearly repair and maintenance cost is $\$ 1211$ /year; yearly electricity cost is $\$ 401$ /year; the discount rate is $8 \%$.

\begin{tabular}{lccr}
\hline Yr & Cash flow $(\$)^{\mathbf{z}}$ & $\begin{array}{c}\text { Discount } \\
\text { factor }\end{array}$ & $\begin{array}{r}\text { Present } \\
\text { value }(\$)\end{array}$ \\
\hline 0 & $-30,000.00$ & & $-30,000.00$ \\
1 & $+5,093.00$ & 0.93 & $+4,715.74$ \\
2 & $+5,093.00$ & 0.86 & $+4,366.43$ \\
3 & $+5,093.00$ & 0.79 & $+4,042.99$ \\
4 & $+5,093.00$ & 0.74 & $+3,743.51$ \\
5 & $+5,093.00$ & 0.68 & $+3,466.21$ \\
6 & $+5,093.00$ & 0.63 & $+3,209.45$ \\
7 & $+5,093.00$ & 0.58 & $+2,971.72$ \\
8 & $+8,093.00$ & 0.54 & $+4,372.40$ \\
& & & $+888.44^{\mathrm{x}}$ \\
\hline
\end{tabular}

${ }^{\mathrm{z}}$ Cash flow was calculated based on one machine operating at its full capacity.

${ }^{\mathrm{y}}$ Discount factor was calculated based on the assumption of the discount rate being $8 \%$ (Julian and Seavert, 2011). ${ }^{\mathrm{x}}$ Net present value.

typical apple orchards in Washington state are 24 ha with a yield of 45 $\mathrm{Mg} \cdot \mathrm{ha}^{-1}$, so four units would be needed for orchards of these sizes. Figure 3 shows the harvest-assist unit quantity needed and benefits under different orchard areas and yields. The general trend demonstrated in Fig. 3 shows that the larger the orchard area, the more benefits the unit could bring. For an average-sized orchard in Washington [yield at 19.9 tons/acre $\left.\left(44.70 \mathrm{Mg} \cdot \mathrm{ha}^{-1}\right)\right]$ and farm size of 58.8 acre $(23.80$ ha) for a typical orchard, New York [17.7 tons/acre (39.60 Mg.ha $\left.{ }^{-1}\right)$, 37.6 acre (15.20 ha)], Michigan $\left[17.3\right.$ tons/acre $\left(38.70 \mathrm{Mg} \cdot \mathrm{ha}^{-1}\right)$, 28.2 acre (11.40 ha)], and Pennsylvania [11.7 tons/acre (26.30 Mg.ha $\left.{ }^{-1}\right)$, 16.1 acre $(6.50$ ha)] (USDA, 2016; Zhang et al., 2016c), four units, three units, two units, and one unit are needed, respectively. As shown in Fig. 3, the technology brings negative benefit to an averagesized Pennsylvania orchard because of the smaller orchard size and lower yields. Using $40 \mathrm{Mg} \cdot \mathrm{ha}^{-1}$ as an example, the economic analysis (Table 6) shows that among the four benefits provided by the harvest-assist device and platform, the increase in harvest and PTT efficiency improvement are the major contributors, which account for $33 \%$ and $61 \%$ of the total benefits, on a per hectare basis.

This analysis makes several assumptions that affect actual costs and benefits. For example, more platforms may be required at one time for harvest, whereas one or two platforms may be needed for nonharvest tasks. Another example is that during harvest, multiple shifts may be run in a day (more than $8 \mathrm{~h}$ of use), or more than one run through an orchard if ripening is not uniform.

Net present value. The NPV analysis result is shown in Table 7 . For 
the example data, which are based on values acquired from Washington State, the NPV was calculated as $\$ 888.44$. Since the calculated NPV is positive, it is worthwhile for owneroperators to purchase the unit.

\section{Conclusions}

The results of the economic analysis show that purchase and utilization of the low-cost apple harvest-assist device and platform can financially benefit small orchards of sizes larger than 7.6 ha with yields larger than $25 \mathrm{Mg} \cdot \mathrm{ha}^{-1}$. For larger apple orchards, the unit is also beneficial, but more than one unit may need to be purchased. For orchards smaller than 4.2 ha, purchasing the unit would not provide an economic advantage. Among the U.S. top four apple production states, typical orchards in Washington, New York, and Michigan, could benefit from this technology, while an average-sized orchard in Pennsylvania may not benefit positively. Benefits from harvest efficiency increase and PTT improvement are the major savings contributors. An NPV analysis over the 8-year life of the unit gave a positive value and therefore suggests it is worthwhile for owneroperators to purchase the harvest-assist unit.

\section{Literature cited}

AgChoice Farm Credit. 2016. 28 July 2016. <http://www.agchoice.com/ home.aspx>.

American Society of Agricultural and Biological Engineers (ASABE). 201la. ASAE Standard D497.7 MAR2011: Agricultural machinery management. Amer. Soc. Agr. Biol. Eng., St. Joseph, MI.

American Society of Agricultural and Biological Engineers (ASABE). $2011 \mathrm{~b}$. ASAE Standard EP496.3 FEB2006 (R2011): Agricultural machinery management. Amer. Soc. Agr. Biol. Eng., St. Joseph, MI.

Automated Ag. 2013. Machines offer a boost with apple harvest. 15 Nov. 2016. <http://automatedag.com/machinesoffer-a-boost-with-apple-harvest $/>$.

Baugher, T.A., J.R. Schupp, K.M. Lesser, R.M. Harsh, K.M. Lewis, C.F. Seavert, and T.D. Auvil. 2009. Mobile platforms increase orchard management efficiency and profitability. Acta Hort. 824:361-364.

Brower, M.A., G.B. Earle-Richardson, J.J. May, and P.L. Jenkins. 2009. Occupational injury and treatment patterns of migrant and seasonal farmworkers. J. Agromed. 14(2):172-178.

Earle-Richardson, G.B., S.B. Fulmer, P.L. Jenkins, C.E. Mason, C. Bresee, and J.J. May. 2004. Ergonomic analysis of New York apple harvest work using a postureactivities-tools-handling (PATH) work sampling approach. J. Agr. Saf. Health 10(3):163-176.

Earle-Richardson, G.B., P.L. Jenkins, A. Freivalds, P.A. Burdick, S.H. Park, C. Lee, C.E. Mason, and J.J. May. 2006b. Laboratory evaluation of belt usage with apple buckets. Amer. J. Ind. Med. 49 (1):23-29.

Earle-Richardson, G.B., P.L. Jenkins, D.S. Strogzta, E.M. Bell, and J.J. May. 2006a. Development and initial assessment of objective fatigue measures for apple harvest work. Appl. Ergon. 37(6): 719-727.

Edwards, W.M. 2015. Estimating farm machinery costs. 10 Mar. 2016. <http:// www.extension.iastate.edu/agdm/crops/ pdf/a3-29.pdf>.

Ellis, K.G., T.A. Baugher, and K.M. Lewis. 2010. Results from survey instruments used to assess technology adoption for tree fruit production. HortTechnology 20:1043-1048.

Fathallah, F.A. 2010. Musculoskeletal disorders in labor-intensive agriculture. Appl. Ergon. 41(6):738-743.

Freivalds, A., S.H. Park, C. Lee, G.B. Earle-Richardson, C.E. Mason, and J.J. May. 2006. Effect of belt/bucket interface in apple harvesting. Intl. J. Ind. Ergon. 36(11):1005-1010.

Fulmer, S.B., L. Punnett, D.T. Slingerland, and G.B. Earle-Richardson. 2002. Ergonomic exposures in apple harvesting: Preliminary observations. Amer. J. Ind. Med. Suppl 2:3-9.

Gallardo, R.K. and S.P. Galinato. 2012. 2012 cost estimates of establishing, producing, and packing Red Delicious apples in Washington. 10 Dec. 2016. <http:// cru.cahe.wsu.edu/CEPublications / FS099E/FS099E.pdf>.

Jones, R.L. 2015. The state of mechanical apple harvesting. 25 Mar. 2016. <http:// www.growingproduce.com/fruits/thestate-of-mechanical-apple-harvesting/>.

Julian, J.W. and C.F. Seavert. 2011. AgProfit ${ }^{\mathrm{TM}}$ : A net present value and cash flow based decision aid for agriculture producers. Agr. Financ. Rev. 71(3):366-378.

Kien Hwa, T. 2008. Sources of net present value gains in the acquisitions of corporate real estate. J. Corp. Real Estate 10(2):121-129.
LeFlufy, M.J. 1982a. Harvest trials with a prototype apple harvester. J. Agr. Eng. Res. 27(5):415-420.

LeFlufy, M.J. 1982b. The design of a prototype apple harvester. J. Agr. Eng. Res. 27(1):51-60.

LeFlufy, M.J. 1983. Apple harvesting by a combing technique. Trans. Amer. Soc. Agr. Eng. 26(3):661-664.

Lehnert, R. 2014. A tale of two harvesters. 15 Nov. 2016. <http://www.goodfruit. com/a-tale-of-two-harvesters $/>$.

Milkovich, M.T. 2013. Apple grower tests harvester in real-world conditions. 29 Feb. 2016. <http://fruitgrowersnews. com/index.php/magazine/article/ apple-grower-tests-harvester-in-realworld-conditions $3>$.

Millier, W.F., G.E. Rehkugler, R.A. Pellerin, J.A. Throop, and R.B. Bradley. 1973. Tree fruit harvester with insertable multilevel catching system. Trans. Amer. Soc. Agr. Biol. Eng. 16(5):844-850.

Mizushima, A. and R. Lu. 2011. Cost benefits analysis of in-field presorting for the apple industry. Appl. Eng. Agr. 27(1): 33-40.

Nordqvist, J. 2016. Apples: Health benefits, facts, research. 24 Feb. 2016. <http://www.medicalnewstoday.com/ articles/267290.php>.

O'Sullivan, J.M., A.P. Wakai, R.G. O'Sullivan, C.A. Luke, and S.P. Cusack. 2004. Ladder fall injuries: Patterns and cost or morbidity. Injury 35(4):429431 .

Produce for Better Health Foundation. 2015. State of the plate, 2015 study on America's consumption of fruit and vegetables. 24 Feb. 2016. <http://www. pbhfoundation.org/pdfs/about/res/ pbh_res/State_of_the_Plate_2015_ WEB_Bookmarked.pdf>.

Peterson, D.L. and S.D. Wolford. 2003. Fresh-market quality tree fruit harvester. Part II: Apples. Appl. Eng. Agr. 19(5): 545-548.

Sazo, M.M., A.D. Marree, and T.L. Robinson. 2010. The platform factorlabor positioning machines producing good results for NY apple industry. New York Fruit Qrtly 18(2):5-10.

Seavert, C.F., J. Freeborn, and S.P. Castagnoli. 2007. Orchard economics: Establishing and producing mediumdensity apples in hood river county. Oregon State Univ. Ext. Serv. Bul. EM 8829-E.

Schmoldt, D.L. 2007. The interplay of biology and engineering for smarter applications. Biol. Eng. 1(2):111-125. 
Schupp, J.R., T.A. Baugher, H.E. Winzeler, M. Schupp, and W.C. Messner. 2011. Preliminary results with a vacuum assisted harvest system for apples. Fruit Notes 76(4): $1-5$.

Smith, G.S., R.A. Timmons, D.A. Lombardi, D.K. Mamidi, S. Matz, T.K. Courtney, and M.J. Perry. 2006. Workrelated ladder fall fractures: Identification and diagnosis validation using narrative text. Accid. Anal. Prev. 38(5): 973-980.

Stevens, J.A., P.S. Corso, E.A. Finkelstein, and T.R. Miller. 2006. The costs of fatal and non-fatal falls among older adults. Inj. Prev. 12(5):290-295.

Taylor, K.M.G., N.K. Green, and D. Physio. 2008. What are the productivity losses caused by musculoskeletal disorders (MSDs)? A review of the current literature. 20 Mar. 2016. <http:// www.workpace.com/assets/Uploads/ White-Papers/Wellnomics-white-paperWhat-are-the-productivity-losses-causedby-musculoskeletal-disorders.pdf $>$.
U.S. Apple Association. 2016. The voice of the U.S. apple industry. 24 Feb. 2016. <http://www.usapple.org/index.php? option $=$ com_content $\&$ view $=$ article $\&$ $\mathrm{id}=179 \&$ Itemid $=285>$.

U.S. Department of Agriculture (USDA). 2012. Bananas and apples remain American's favorite fresh fruits. 24 Feb. 2016. $<$ http://www.ers.usda.gov/dataproducts/chart-gallery/detail.aspx? chartId=30486 $>$.

U.S. Department of Agriculture (USDA). 2016. Noncitrus fruits and nuts 2015 summary. 1 Oct. 2016. <http://usda.mannlib. cornell.edu/usda/current/NoncFruiNu/ NoncFruiNu-07-06-2016.pdf>.

U.S. Energy Information Administration. 2016. State electricity profiles. 12 Nov. 2016. <http://www.eia.gov/electricity/ state $/>$.

Zhang, Z. 2015. Design, test, and im provement of a low-cost apple harvestassist unit. PhD Diss., Dept. Agr. Biol.
Eng., Pennsylvania State Univ., University Park, PA.

Zhang, Z., P.H. Heinemann, J. Liu, J.R. Schupp, and T.A. Baugher. 2014. Design, fabrication, and testing of a low-cost apple harvest-assist device. Amer. Soc. Agr. Biol. Eng. Paper No. 141839738.

Zhang, Z., P.H. Heinemann, J. Liu, J.R. Schupp, and T.A. Baugher. 2016a. Design and field test of a low-cost apple harvest-assist unit. Trans. Amer. Soc. Agr. Biol. Eng. 59(5):1149-1156.

Zhang, Z., P.H. Heinemann, J. Liu, J.R. Schupp, and T.A. Baugher. 2016b. Development of mechanical apple harvesting technology: A review. Trans. Amer. Soc. Agr. Biol. Eng. 59(5):1165-1180.

Zhang, Z., A.K. Pothula, and R. Lu. 2016c. Economic analysis of a selfpropelled apple harvest and in-field sorting machine for the apple industry. Amer. Soc. Agr. Biol. Eng. Paper No. 2456644. 